\title{
Doing Things with Lists-Enumeration in Arabic Prose
}

\author{
Christian Junge \\ Philipps-Universität Marburg \\ christian.junge@staff.uni-marburg.de
}

\begin{abstract}
This article discusses the performative function of enumeration in Arabic prose. Bringing together a great variety of word lists from classical to modern prose (including the 1001 Nights, al-Tawhīdī, al-Suyūṭī, al-Shidyāq, and Darwīsh), it unveils their often neglected importance to literature by drawing from an emerging scholarship on enumeration. Focusing on "enumerative games" (Mainberger), the article does not ask what the enumerated elements mean, but how the act of enumerating produces meaning. In the first part, the article discusses elements central to the poetics of the enumerative (including items, length, arrangement, and frame). In the second part it deals with the politics of enumeration in the example of al-Shidyāq's al-Sāq 'alā al-sāq fì mā huwa al-Fāriyāq (1855). The article seeks to provide a basic approach to enumeration and argues that enumerative games in literature perform acts of cultural politics.
\end{abstract}

\section{Keywords}

enumeration - list - nahḍh - lexicography - Aḥmad Fāris al-Shidyāq - al-Sāq 'alā al-sāq - al-Suyūṭi - 1001 Nights - al-Tawhị̂̀ī - Maḥmūd Darwīsh

\section{Lost in Lists}

Enumeration is an often neglected and yet significant device in world literature. In regard to European and American prose literature, one may think of François Rabelais's (d. 1553) excessive compilations, Hermann Melville's (d. 1891) obsessive classifications, or Jorge Luis Borges's (d. 1986) uncanny 
lists. ${ }^{1}$ Arabic literature too has made a genuine and largely overlooked contribution to enumeration in world literature. Drawing from a long and rich philological and lexicographical tradition, classical and modern prose literature is often interwoven with and inspired by word lists. The reader comes across satirical lists in al-Tawhīdī (d. 1023) and praising lists in Darwīsh (d. 2008), affective compilations in as-Suyūți (d. 1505) and excessive compilations in the 100 Nights, or erotic inventories and protofeminist catalogues in al-Shidyāq (d. 1887), to mention only some examples that will be discussed later. ${ }^{2}$

While enumeration as 'archaic' epistemic practice was extensively discussed by scholars of ancient Oriental literature, ${ }^{3}$ scholars of 'later' literatures and cultures have often overlooked enumeration as a distinct device, though we find scattered reflections. Michel Foucault famously starts The Order of Things with a discussion of the epistemic force of Borges's encyclopedic lists, ${ }^{4}$ while Roland Barthes identifies in The Pleasure of the Text the list as a point of transition from the referential to the self-referential function of language, where the word becomes a "lexicographical artifact." ${ }^{5}$ In recent cultural and literary studies, however, enumeration has received more thorough attention. In regard to the epistemic function, Julia Bray discusses lists in classical Arabic literature as a form of organizing, memorizing, and appropriating epistemes. In the latter regard, "lists often cut across the grain of familiar, lazy thought and are a form of conceptual training, or an attempt at it." Liam Cole Young approaches

1 For Rabelais, see Umberto Eco, The Infinity of Lists: From Homer to Joyce, trans. Alastair McEwen (London: MacLehose Press, 2012), 244-277; for Melville, see Robert E. Belknap, The List: The Uses and Pleasures of Cataloguing (New Haven: Yale University Press, 2004), 120-167; for Borges, see Liam Cole Young, List Cultures: Knowledge and Poetics from Mesopotamia to BuzzFeed (Amsterdam: Amsterdam University Press, 2017), 135-142.

2 For the philological and lexicographical tradition, see Ramzi Baalbaki, The Arabic Lexicographical Tradition: From the 2nd/8th to the 12th/18th Century (Leiden: Brill, 2014); Muhsin Al-Musawi, The Medieval Islamic Republic of Letters: Arabic Knowledge Construction (Notre Dame: University of Notre Dame Press, 2015), 59-146.

3 In 1936, Wolfram von Soden coined the influential term "Listenwissenschaft" (list science) for enumerative Sumerian knowledge production, see Markus Hilgert, "Von 'Listenwissenschaft' und 'epistemischen Dingen'. Konzeptuelle Annäherungen an altorientalische Wissenspraktiken," Zeitschrift für allgemeine Wissenschaftstheorie 40:2 (2009), 277-309.

4 Michel Foucault, The Order of Things: An Archeology of Human Sciences (New York: Pantheon Books, 1971), xv-xxiv.

5 Roland Barthes, The Pleasure of the Text, trans. Richard Miller (New York: Hill and Wang, 1975), 27.

6 Julia Bray, "Lists and Memory: Ibn Qutayba and Muḥammad b. Ḥabīb," in Culture and Memory in Medieval Islam: Studies in Honour of Wilferd Madelung, ed. Farhad Daftary and Josef W. Meri (London: I. B. Tauris, 2003), 214. 
enumeration from the perspective of cultural practices and media materialism discussing, for instance, pop charts, buzz feeds, and computer algorithms. ${ }^{7}$ In regard to the aesthetic function of enumeration, Umberto Eco analyzes the "voraciousness" 8 of long lists in Western literature that makes it (nearly) impossible to read every item; rather, it seeks to induce the effect of infinity and abundance. ${ }^{9}$ And Tarek El-Ariss describes the lists of the nineteenth-century al-Shidyāq as "word activation (taf'il al-mufradāt)"10 by sound, rhythm, and association that is "activating the senses (taf'il al-hawäs [sic])."11 These and other studies question the often claimed archaic simplicity, arbitrary inconsistency, and tedious monotony of word lists. ${ }^{12}$ They approach lists as a site of meaning creation that produces concepts of knowledge or challenges power, and they analyze enumeration as an ambiguous aesthetic device that allows for multiple practices and effects.

$7 \quad$ Young, $45^{-129}$.

8 Eco, 371.

9 Ibid., $15-18$.

10 Tarek El-Ariss, "Review of Ahmad Faris al-Shidyaq. Leg Over Leg, or the Turtle in the Tree, Concerning the Fāriyāq, What Manner Might He Be. trans. Humphrey Davies," Arab Studies Journal 24:1 (2016), 286.

11 El-Ariss, 288.

12 For Cultural Studies, see also Hilgert; Lucie Doležalová, ed., The Charm of a List: From the Sumerians to Computerised Data Processes (Newcastle: Cambridge Scholars Publishing, 2009); François Jullien, ed., Die Kunst, Listen zu erstellen, trans. Ronald Vouillié (Berlin: Merve, 2004). For Western literature, see also Belknap; Sabine Mainberger, Die Kunst des Aufzählens. Elemente zu einer Poetik des Enumerativen (Berlin: de Gruyter, 2013); Sophie Milcent-Lawson, Michelle Lecolle, Raymond Michel, eds., Liste et effet liste en littérature (Paris: Classiques Garniers, 2013). For older and recent studies on Arabic literature see also Marc Bergé, Pour un humanisme vécu: Abû Hayyân al-Tawhîdî (Damascus: Institut Français de Damas, 1979), 400-406; Thomas Hefter, The Reader in al-Jāhiz: The Epistolary Rhetoric of an Arabic Prose Master (Edinburgh: Edinburgh University Press, 2014), 39-41, 113 et passim; Katia Zakharia, "Aḥmad Fāris al-Šidyāq—auteur de Maqāmāt," Arabica 52:4 (2005), 509-521; Lois A. Giffen, "al-Nafzāwī," in Essays in Arabic Literary Biography, vol. 2, 1350-1850, ed. Joseph E. Lowry and Devin J. Stewart (Wiesbaden: Harrassowitz, 2009), 316-317; Mattityahu Peled, "The Enumerative Style in Al-Sâq 'alā al-sâq," Journal of Arabic Literature 22:1 (1991), 127-145; Fawwāz Țarābulusī and 'Azīz al-'Aẓmah, "Ṣu'lūk an-nahdawiyyìn al-'arab. Muqaddima," in Silsilat al-a'māl al-majhülah: Aḥmad Fāris al-Shidyāq (London: Riyāḍ al-Rayyis, 1995), 32-34; Christian Junge, "I Write, Therefore I Am: Metafiction as Self-Assertion in Mustafa Dhikri's Much Ado About a Gothic Labyrinth," in Arabic Literature, Postmodern Perspectives, ed. Angelika Neuwirth, Andreas Pflitsch, and Barbara Winckler (London: Saqi, 2010), 453-455; Christian Junge, Die Entblößung der Wörter. aš-Šidyāqs literarische Listen als Kultur- und Gesellschaftskritik im 19. Jahrhundert (Wiesbaden: Reichert, 2019). For a discussion of some of the misconceptions surrounding lists, see Hilgert, 278-282. 
In her book on the art of enumerating, Sabine Mainberger draws attention to the "enumerative games"13 of texts. Rather than approaching enumeration as a set of fixed forms and functions, she focuses on enumeration as a versatile performative act that matters in different ways. ${ }^{14}$ In a broad reading of western texts, she explores for instance performatives of defining, memorizing, and desiring. Taking Mainberger's approach as a starting point, this article surveys "how to do things with lists"15 in Arabic prose literature. ${ }^{16}$ For J. L. Austin, performative utterances do not describe but do something. ${ }^{17}$ While Austin focuses on illocutionary speech acts taking place in conventional situations, enumeration in and as literature are often perlocutionary speech acts taking place in semi- or non-conventional situations, where the speaker (e.g., the author, narrator, or character) does not have full control of what enumerating does for the text, reader, or listener. ${ }^{18}$ At the same time, certain practices, institutions, and discourses suggest particular ways of reading enumeration. In order to understand enumeration in Arabic literature and world literature, it is important not only to make the lists themselves visible, but also the ways in which they are used and received. In this regard, Michael Allan argues that world literature is not only about the canonized body of texts, but about institutionalized ways of reading, i.e., "defining not just what but how to read."19 This also relates to the question of what enumeration in and as literature may mean in different concepts of literature, practices of reading, and discourses of culture.

As a starting point to contour the volatility of enumeration, one might take the classical term for 'enumeration' that is at the same time the modern technical term for 'narration,' namely, sard. The North African lexicographer Ibn Manẓūr (d. 1311) provides a concise definition of enumeration in his dictionary Lisān al-Arab. "Sard in regard to language: presenting one thing next to the other, in a good order, one thing follows immediately and consecutively after another." ${ }^{20}$ The term refers to ways of quoting ahäditth (sayings of the prophet) and reading suwar (Quranic suras), but also presenting words one after the

13 Mainberger, 12.

14 Ibid., 6-13.

15 Ibid., 12.

16 Enumeration is also significant for poetry, see e.g. Belknap, 37-119. For pragmatic reasons, enumerative poetry is not part of this article.

17 J. L. Austin, How to Do Things with Words (Cambridge: Harvard University Press, 1962), 12-13.

18 Ibid., 94-131.

19 Michael Allan, In the Shadow of World Literature: Sites of Reading in Colonial Egypt (Princeton: Princeton University Press, 2016), 4; italics in the original.

20 Jamāl al-Dīn Muhammad ibn Mukarram Ibn Manẓūr, Lisān al-Arab, ed. Aḥmad Fāris [al-Shidyāq], vol. 4 (Bulāq: al-Mațba'ah al-Mīriyyah, 1883), 195:

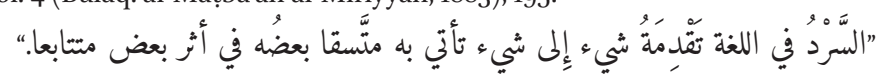


other. In regard to material culture, sard designates the way of manufacturing for instance a chain mail "by inserting the rings one into another."21 A modern dictionary like al-Munjid still relates the classical meanings, but now neatly differentiates between "narrating a story" (sarada qișșatan) and "enumerating facts" (sarada waqāïian), separating narration from enumeration. ${ }^{22}$ In literary theory, the term sard has become the key term for narrative. ${ }^{23}$

Rather than pruning the term or opting for one or another meaning, my article reads enumeration as a complex epistemic and aesthetic device of literature that makes different things in different texts and contexts. In a first step, the article seeks to show the multitude and diversity of lists in Arabic prose by choosing four examples from different literary periods and prose genres: examples from al-Tawhīiñ's classical satire Akhlāq al-wazìrayn, al-Suyūțì's postclassical Adab-compilation al-Wishähfí fawāìd al-nikāh (The Belt: on the Merits of Mating), the popular corpus of the 1001 Nights, and Darwish's modern account Dhäkirah li-l-nisyān (Memory for Forgetfulness). Bringing these examples together, the article analyzes for each of them an important trait of enumerative poetics, namely, items, length, arrangement, and frame. These poetical elements provide the basic tools to describe and analyze enumerations. In the second step, the article discusses the politics of enumeration. Taking the nineteenth-century al-Shidyāq and his literary-lexicographical al-Sāq 'ala l-sāq (Leg Over Leg, 1855) as an example, it focuses on enumerative epistemes in the reformist discourse of the nahdah ('awakening'). It asks about the performative practices of making a modern civilization and investigates in particular how word lists were used and read during the nahdah. This article examines the poetics and politics of enumeration in Arabic prose; it seeks to provide the rudiments for a general approach to enumeration and argues, with al-Shidyāq's $a s-S \bar{a} q$ as a case study, that lists can 'do' politics.

\section{What's in a List? Elements for a Poetics of the Enumerative}

Ibn Manzūr describes enumeration as a seamless and well-ordered linguistic presentation, Mainberger, in contrast, understands it as a "fragmented language"; 24 both are flagging the extreme poles for the poetics of the

21 Edward William Lane, An Arabic-English Lexicon Derived from the Best and Most Copious Eastern Sources, vol. 4 (London: Williams and Norgate, 1872), 1346; italics in the original.

22 Al-Munjid fì l-lughah al-'arabiyyah al-mu'āṣirah, ed. Anțūn Ni'mah, 'Iș̣āam Mudawwar, Lūwīs 'Ajīl, Mitrī Shammās, 2nd ed. (Beirut: Dār al-Mashriq, 2001), 661.

23 Lațīf Zaytūnī, Mứcam muștalaḥāt naqd al-riwāayah: 'arab̄̄inklīzī-faransī (Beirut: Maktabat Lubnān Nāshirūn, 2002), 105-106.

24 Mainberger, 12; my translation. 
enumerative, i.e., cohesion and rupture. This "versatility"25 of enumeration, as Belknap puts it, results in an abundance of forms like the list, a pure enumeration without "descriptive enhancement"; ${ }^{26}$ the catalogue, a contextualized compilation; and the lexicon, a highly structured inventory. ${ }^{27}$ The list is a radically reduced and therefore a highly ambiguous kind of textuality, often very different from narratives. ${ }^{28}$ Due to this ambiguity, practical lists are often prone to be read as poetical lists and vice versa, as Eco remarks, ${ }^{29}$ and the epistemic function and the aesthetic function are often closely interlinked. In order to approach compilations, four elements may be relevant for the analysis:

\section{1). Items}

Compilations consist of items conjunct with each other. The size of an item may range from a single word to a whole story. In this regard, the roor Nights may be considered a compilation of stories and nights. However, the smaller the size of item, the stronger the enumerative effect normally is. In addition, the enumerative effect also depends on the conjunction of the items. This may be a whole phrase, like the formulaic phrases at the end of a night in the 1001 Nights, a conjunction like 'and,' a punctuation mark like the comma, or simply nothing. Small items and succinct conjunctions foreground the act of iteration that is, according to Mainberger, a basic feature of the act of enumerating: to put one item after another after another. ${ }^{30}$ Arabic literature often connects items by brief and repetitive conjunctions, using in classical texts the conjunction $w a$ - ('and') and in modern texts commas or full stops; this results often in a highly paratactical structure of minimalized subordination and shattered cohesion. $^{31}$

One example for such a paratactical list appears in the autobiographical text Dhākirah li-l-nisyān by the Palestinian poet Maḥmūd Darwīsh. Published at the height of the Lebanese civil war, it painstakingly describes the appalling living conditions in Beirut under the Israeli siege in $1982 .{ }^{32}$ The small things in life now become meaningful, like coffee, for instance, but also water. Crucially

\footnotetext{
25 Belknap, 2.

26 Ibid.

27 Ibid., 2-3.

28 Mainberger, 6-13.

29 Eco, 370-377.

3о Mainberger, 9 .

31 Mainberger, 7-8.

32 See e.g. Patrick Williams, "Besiege Your Siege!': Mahmoud Darwish, Representation, and the Siege of Beirut," in The Ethics of Representation in Literature, Art, and Journalism: Transnational Responses to the Siege of Beirut, ed. Caroline Rooney and Rita Sakr (London: Routledge, 2013), 56-70.
} 
deprived of water, Darwish plunges into a meditation on the existential meaning of water that culminates in a list of words related to water: "Water. Waters. Waterfall. Rapids. Cataract. Cascade. Snow. Ice. Hail. Backwater. Backwash. $[\ldots]$ And so on ... and so on ... and so on." ${ }^{33}$ Darwīsh takes the words explicitly from the immense lexical thesaurus al-Mukhașas (The Specialized One) compiled by the Andalusian lexicographer Ibn Sīdah (d. 1066). Following the principles of classical Arabic philology, Ibn Sīdah provides for nearly every word the name of the transmitter $(r \bar{a} w \bar{\imath})$, a definition, and explanation, and sometimes probative verses (shawāhid). ${ }^{34}$ Darwīsh, in contrast, radically erases the names and verses, definitions and explanations. He cuts the items short and thereby exposes the bare word material; he strips the language naked (ta'riyat al-lughah), as one could say in conjunction with Fawwāz Ṭarābulusī and 'Azīz al-Azmah: ${ }^{35}$ Water. Full stop. Waters. Full stop. Waterfall. Full stop. The brief and iterative punctuation mark produces a dense minimalism. Turning the exhaustive lexicographical catalogue into a dense lexical list, the accelerated speed and rhythm increase the intensity. "The sound of water," Darwīsh meditates, "is freedom, is humanity itself."36 In the state of thirst and suffering, it performs a linguistic cascade of water; language gushes freedom and humanity, even and especially in times of war.

\section{2). Length}

A compilation consists of a fixed number of items, so counting the items is a first step towards determining enumerative length. ${ }^{37}$ A reader of Arabic literature, and especially classical literature infused by lexicography, comes frequently across lists of 30 to 100 words, often used "as a touchstone of pride

33 Maḥmūd Darwīsh, Dhākirah ... li-l-nisyān. Al-Zamān: Bayrūt. Al-Makān: Yawm min ayyām ābb 1982, 3rd ed. (Amman: al-Mu’assasah al-'Arabiyyah li-l-Dirāsāt wa-l-Nashr, 1990), 46-47:

"ماء .ماءة .مويه .أمواه .مياه .ماهة .بلال .رجع .أبيض .أسود .عتيق [...] .وغيرها ..وغيرها ..وغيرها.".. Mahmud Darwish, Memory for Forgetfulness: August, Beirut, 1982, trans. Ibrahim Muhawi (Berkeley: University of California Press, 1995), http://ark.cdlib.org/ark:/13030/ $\mathrm{ft} 1 \mathrm{zogn}_{7} \mathrm{~g} 7$. This is not meant as a literal translation by Muhawi; note my modification at the end.

34 Ibn Sīdah, Al-Mukhașșaș, vol. 9 (Bulāq: al-Mațba'ah al-Kubrā al-Amīriyyah, ca. 19o1), 130144. See Baalbaki, 274-279.

35 Ṭarābulusī and al-'Aẓmah, 32.

36 Darwīsh, Dhākirah, 44:

Translation in Darwish, Memory.

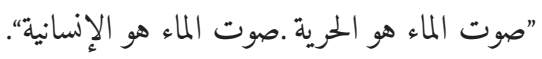

37 For enumerative length, see Mainberger, 10. 
in the richness of Arabic." ${ }^{38}$ But length is also made by claims. In this regard, lists often swing, as Eco says, "between a poetics of 'everything included' and a poetics of the 'etcetera."'39 They can claim to be either comprehensive or exemplary. Importantly, both types can evoke the sensation of infinity, the first by an "intolerable swarm" 40 of simply too many items, the second by opening up the incomplete enumeration with an imaginative "etcetera" for a quasi-neverending enumeration. ${ }^{41}$

The textual corpus of Alf Laylah wa-laylah (1001 Nights) offers a telling example of a 'too long' enumeration. ${ }^{42}$ On the 295th night, Scheherazade relates the story of two people who claim ownership of the same bag. To find out who the legitimate owner is, the judge asks both to describe its contents. The first potential owner lists precious sticks for applying kohl, handkerchiefs, and candlesticks, but also a camel and even a palace, all in all some 45 items. The second one lists a dog kennel, a boys' school, and a ruined house, but also the cities Basra and Baghdad, all in all some 20 items. Hearing the latter description, the first tries to trump the second with an additional list of nearly 20 items, and the second the first with some 90 items. When the bewildered judge opens the bag, it contains but "bread, lemons, cheese, and olives."43 This is the story of two tricksters, who are trying to gain material profit by eloquently describing the content of a bag they don't own. In the heat of the dispute (munāzara), they are carried away by the act of enumeration; they simply forget to stick to plausible items and to a plausible length. It is a story about the seductive force of long, or better yet, too long compilations; in the magical framework of the 1001 Nights it is a tale about the magical charm of lists.

\section{3). Arrangement}

A compilation may be described as the arrangement of items. For Ibn Manzūr, enumeration demands "a good order," and many lists in Arabic literature follow at least a specific order. Items may be arranged for instance according to their importance or features, their letters or meaning, their sound or rhyme.

\footnotetext{
$38 \quad$ Giffen, 317 .

39 Eco, 7.

40 Ibid., 18.

41 In this regard see Darwīsh's list ending with the repetitive formula "and so on ... and so on ... and so on ..." evoking a nearly endless list.

42 This story is part of the Bulāq and Calcutta II editions and not to be found in older corpora. See Muhsin Mahdi, The Thousand and One Nights (Leiden: Brill, 1995), 97-126.

43 Kitāb Alf laylah wa-laylah, ed. Muhammad Qiț̣ah al-'Adawī, 2nd ed. (Bulāq: Mațba'at 'Abd al-Rahmmān al-Rushdī, 1862/63), 469. For a postmodern rewriting of this enumerative story, see Junge, $453-455$.
} 
Not all lists, however, apply the order consistently or even have an apparent order, thereby producing what Eco calls "chaotic enumeration." ${ }^{44}$ Instead they may facilitate a non-linear, rhizomatic knowledge production, like in Hilgert's analysis of word lists from the ancient Orient. ${ }^{45}$

In regard to lists in rhymed prose $\left(s a^{j}\right)$, the Egyptian polymath Jalāl al-Dīn al-Suyūṭī (d. 1505) provides a remarkable selection in his belletrist compendium al-Wishāh fi fawāid al-nikāh, in which he gathers erotic material from different fields of knowledge and dedicates one section to rhymed prose and poetry. ${ }^{46}$ One example: "The Persian King spoke to his sons: Describe to me your desire for women. The first said: I like qudūd and khudūd and nuhüd [stature and cheeks and breasts]. The second said: I like ațrāf and $a^{t} t \bar{a} f$ and $\operatorname{ard} \bar{a} f$ [glances and body and buttocks]. The third said: I like thughür and nuhür and shu'ür [mouths and necks and hairs]." ${ }^{47}$ Do these answers refer to precise sexual preferences? It is important here to have the origins of saj' in mind. Used by pre-Islamic soothsayers for their mantic speech, it is a constitutive part of the Islamic revelation and forms a part of Qurānic aesthetics, while from the tenth century it turned into a writing style of official correspondence and of some literary genres, but has been mostly abandoned since the nineteenth century. ${ }^{48}$ In the discussed example, and in other examples of Arabic literature, saj is, however, not a formulaic style of writing, but a mode of being affected, i.e., becoming a medium of intensity. ${ }^{49}$ When the Persian people start to speak on desire, they fall in desire. They are not pinpointing their precise preferences (e.g., qudūd, but not ațräf or thughür), but rather allowing the language to unfold desire. Saj' is, using the terms of El-Ariss, an activation of words (taf'il al-mufrādāt) resulting in an activation of the senses (taf'il al-hawāṣs). ${ }^{50}$

44 Eco, 321.

45 Hilgert, 288-308.

46 See Jaakko Hämeen-Anttila, "Al-Suyūṭī and Erotic Literature," in Al-Suyūțī: A Polymath of the Mamlūk Period, ed. Antonella Ghersetti (Leiden: Brill, 2016), 227-232.

47 Jalāl al-Dīn al-Suyūṭī, al-Wishāh fí fawā̉id al-nikāḥ, ed. Țal'at Ḥasan 'Abd al-Qawī (Damascus: Dār al-Kitāb al-'Arabī, n.d.), 273-274:

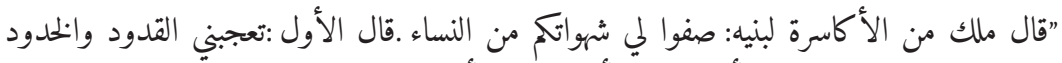

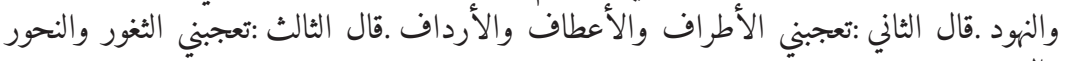

$$
\begin{aligned}
& \text { والشعور". }
\end{aligned}
$$

In comparison with manuscripts, quḍuff, khuḍüf, and shufür have been corrected to qudūd, khudūd, and shu'ūr.

48 See E. K. Rowson, "Saj," in Encyclopedia of Arabic Literature, ed. Julie Scott Meisami and Paul Starkey (London: Routledge, 1998), 677-678.

49 See Suleiman Jubran, "The Function of Rhyming Prose in al-Sāq 'alā al-sāq," Journal of Arabic Literature 20:2 (1989), 148-158.

50 El-Ariss, 286-288. 
Enumerative $s a j$ ' is an affective formula that produces an embodied meaning: speaking about desire here is creating this desire in the first place.

\section{4). Frame}

Every compilation has a textual frame that allows the reader to understand the compilation in [a] specific way. These frames are extremely polymorph and may be found in the form of an introduction, title, narrative, commentary, or isnād (chain of transmitters), to give only a few examples from Arabic literature. According to Mainberger, enumeration is a "fragmented language" and "all elements on a list are per definitionem decontextualized." ${ }^{51}$ In order to allow for enumerative games, these items have to be at least vaguely re-contextualized or neo-contextualized. This frame, as I call it, is a kind of hermeneutical game manual that prevents arbitrariness and yet facilitates a multitude of readings.

One playful frame is offered by the satirical book Akhlāq al-wazirayn by the Iraqi homme de lettres Abū Ḥayyān al-Tawhīìi (d. 1023). ${ }^{52}$ Here, the reader finds a list that does not make sense without the frame: "and what is a zihliq and what is a hiblac [...] and what is an 'arawmat and what is a sarawmat". ${ }^{53}$ It holds thirty-three words, conjuncts repeatedly with wa-ma ('and what is'), falls eventually into saj' ('arawmat and sarawmat,' 'afshalïl and qafshalïl, etc.), and contains so-called gharīb words, i.e., archaic and arcane words. ${ }^{54}$ But it is quite unclear what the list could mean or how to translate for instance zihliq, i.e., as 'fat donkey,' 'a lamp's fire,' or 'strong wind. 55

The frame reads as follows: "He [i.e., the vizier and lexicographer Ibn 'Abbād] said to the poet al-Tamīmi: How could you write poetry, when you don't know what a zihliq is and what a hibla' is [...] and what an 'arawmat is and what a sarawmat is." ${ }^{66}$ Due to the frame, the items are now re-contextualized in an authoritative list of ghari b words that must be used in poetry. Indeed, some Arab poets were eager to use gharïb words, as classical Arab lexicographers were to

$51 \quad$ Mainberger, 21.

52 See Mary St. Germain: "Abū Hayyān al-Tawḥīdī," in Essays in Arabic Literary Biography. 925-1350, ed. Terri De Young, Mary St. Germain (Wiesbaden: Harassowitz, 2011), 353-354.

53 Abū Hayyān al-Ṭawḥ̄īī, Akhlāq al-wazīrayn al-Ṣāḥib Ibn 'Abbād wa-Ibn al-'Amìd, ed. Muhammad Ibn Tāwīt al-Qatanjī (Beirut: Dār Ṣādir, 1992), 482-483:

54 See Baalbaki, 36-45.

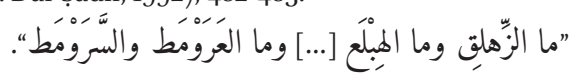

55 Al-Tawhīì̄, 483n3.

56 Al-Tawhīìì, 483:

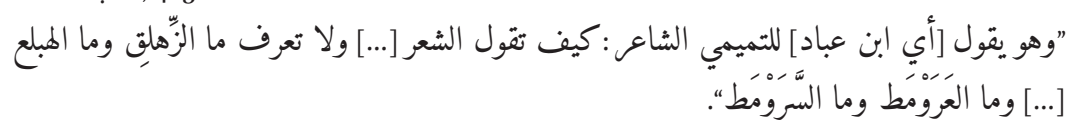


collect them in gharīb thesauri, ${ }^{57}$ often fetishizing the gharīb word as a kind of "lexicographical artifact," ${ }^{58}$ as Barthes would say. But since enumerative games are often more complex, the enumeration of al-Tawhīdī is framed by another frame: "al-Khalīlī said to me: The man [i.e., Ibn 'Abbād] is mad. [...] He said to the poet al-Tamimi: How could you write poetry, when you don't know what a zihlig is and what a hibla' is [...] and what an 'arawmat is and what a sarawmat is." ${ }^{59}$ This double-frame of transmitters neo-contextualizes the gharïb words in a satirical list. It collects, as Geert Jan van Gelder points out, words considered by some Arabs as particularly ugly due to their sound and is thereby "ridiculing the use of highfalutin diction (tashäduq or tashadduq)." ${ }^{60}$ It is not directed against inappropriate lexical meanings (e.g., zihliq referring to 'donkey' or 'lamp's light'), but inappropriate word materials and language attitudes as embodied by the vizier and lexicographer Ibn 'Abbād (d. 995). ${ }^{61}$ Launching the enumerative game in this framework, the conjunction wa-ma ('and what is') is no longer addressed against al-Tamīmī, but turns now against Ibn 'Abbād, as if it were saying: What is the use of this ugly word? It develops with every repetition a stronger satirical force seeking to expose not only these seemingly ugly lexicographical artifacts but also their related embodied linguistic habitus.

Lists are, as Belknap says, "plastic, flexible structures in which an array of constituent units coheres through specific relations generated by specific forces of attraction." ${ }^{62}$ In order to approach them, this article suggests scrutinizing their items, length, arrangement, and frame. These elements are basic features of every compilation; however, their analysis is but a starting point to understand enumerative games. The specific relations and forces of attraction that Belknap mentions are engendered by discourses that do not only regulate what to put on a list and what not, but also how to use or read a list.

\footnotetext{
57 See Baalbaki, 63-99.

58 Barthes, 27.

59 al-Tawhīìi, 483:

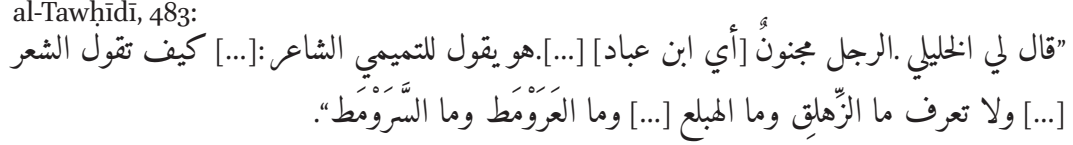

6o GeertJan van Gelder, Sound and Sense in Classical Arabic Poetry (Wiesbaden: Harrassowitz, 2012), 222.

61 For his dictionary, see Baalbaki, 319-322. For his concept of poetry and rhymed prose, see Maurice Pomerantz, Licit Magic. The Life and Letters of al-Ṣăhib b. 'Abbād (d. 385/995) (Leiden: Brill, 2018), 79-86; 187-19o.

Belknap, 2.
} 


\section{Lists That Matter: the Enumerative Politics of al-Shidyāq's $a l-S \bar{a} q(1855)$}

"Listing is," Liam Cole Young writes, "a cultural technique that performs ontic operations that inscribe concepts and categories upon which technical systems and social institutions are built."63 By this ontic operation, compilations and inventories take part in making the world. In order to understand the politics of enumerative games in literature, it is, following Allan, important to know how lists are used and read. This relates to the discursivity of enumeration. A lengthy list of synonyms, for instance, may be used very differently in various contexts, conveys different arguments, and makes different meaning. Moving from enumerative poetics to politics, the second part of this article approaches Aḥmad Fāris al-Shidyāq's enumerative games as a way of engaging in contemporary reform debates on language, culture, and society.

The so-called nahdah ('awakening') of the long nineteenth century was characterized by far-reaching transformations. These included the implementation of printing presses and new forms of schools, and the emergence of newspapers and journals that facilitated a new readership and public sphere with heated debates about the classical language, cultural identity, and the new woman. ${ }^{64}$ For the nahdah, enumeration was an important cultural technique of making contemporary knowledge through encyclopedias, travelogues, and schoolbooks. Within the "lexicographical turn"65 of the nahdah, as Nadia Bou Ali calls it, dictionaries, thesauri, language textbooks, and linguistic treatises became crucial constituents of nineteenth-century discourses of civilization and the nation trying to shape society and culture. Moreover, the technology of the printing press together with intensified networks with Europe and Asia

\section{Young, 18.}

64 For studies on the Syro-Lebanese nahdah, see e.g. Fruma Zachs and Sharon Halevi, Gendering Culture in Greater Syria. Intellectuals and Ideology in the Late Ottoman Period (London: Tauris, 2015); Abdelrazzak Patel, The Arab Nahda. The Making of the Intellectual and Humanist Movement (Edinburgh: Edinburgh University Press, 2013); Sharbil Dāghir, al-Arabiyyah wa-l-tamaddun. Fù ishtibāh al-alāqāt bayn al-nahdah wa-l-muthāqafah wa-l-ḥadāthah (Beirut: Dār an-Nahār, 2008); Mājid Fakhrī, al-Harakāt al-fikriyyah wa-ruwwāduhā al-lubnāniyyyūn fì 'aṣr al-nahḍah: 1800-1922 (Beirut: Dār al-Nahār, 1992), 7-138.

65 Nadia Bou Ali, "Collecting the Nation: Lexicography and National Pedagogy in al-nahda al-arabiyya," in Archives, Museums and Collecting Practices in the Modern Arab World, ed. Sonja Mejcher-Atassi and John Pedro Schwartz (Farnham: Ashgate, 2012), 36; see also Patel, 75-158. For a postclassical 'lexicographical turn,' see Musawi, 89-118. 
facilitated the emergence of a new macrotypography. ${ }^{66}$ The text presentation in the Arabic book was making the enumerative items more visible and accessible by using vertical lists, adding paragraph breaks after lemmas, splitting the text into two or more columns, and supplementing indices for lists in books.

For this "lexicographical turn," al-Shidyāq plays a central and yet eccentric role. Born around 1805/6 in Lebanon, this cosmopolitan intellectual spent his life for various reasons in Cairo, Malta, London, Paris, Tunis, and Istanbul. ${ }^{67}$ Taking the Arabic language as his true homeland, he published extensively on language pedagogy, lexicographical criticism, and philology, and provoked many controversial debates with his books and articles. ${ }^{68}$ His lexicographicliterary al-Sāq anticipates many ideas of his later works, but engages with them here in a more experimental and radical way. From a broader perspective, one could say that it takes up central questions of the nahdah, but often suggests eccentric answers to them. The text narrates the semi-autobiographical story of the protagonist al-Fāriyāq moving from Mount Lebanon to London and Paris; it reflects on contemporary Arab and European societies; and it enumerates at great length words of the classical Arabic language, mostly synonyms and ghari $b$ words that infuse narration and reflection. ${ }^{69}$ In close collaboration with the Parisian typesetter A. Perrault, al-Shidyāq used vertical enumeration and indices for wordlists; and thanks to Perrault's technical knowledge and equipment, as the back cover endorsement claims, al-Shidyāq was able to

66 Hala Auji, Printing Arab Modernity: Book Culture and the American Press in NineteenthCentury Beirut (Leiden: Brill, 2016), 37-57.

67 See Rebecca Johnson, "Foreword," in Ahmad Fāris Al-Shidyāq, Leg Over Leg or the Turtle in the Tree concerning The Fāriyāq What Manner of Creature Might He Be, ed. Humphrey Davies, 4 vols. (New York, New York University Press, 2013-2014), vol. 1, ix-xl; Muhammad al-Hādī al-Mațwī, Aḥmad Fāris al-Shidyāq 1801-1887: Hayātuhu wa-āthāruhu wa-ārāuhu fì al-nahḍah al-'arabiyyah al-ḥadīthah, 2 vols. (Beirut: Dār al-Gharb al-Islāmī, 1989), vol. 1 $45^{-233}$.

68 See e.g. Muḥammad Sawāîi: al-Hadāthah wa-muștalahạt al-nahḍh al-arabiyyah fì qarn at-tāsic 'ashar. Dirāsah fì mufradāt Aḥmad Fāris al-Shidyāq fı̀ jarīdat (al-Jawāìb) (Beirut: al-Mu’assasah al-'Arabiyyah li-l-Dirāsāt wa-l-Nashr, 2013); Adrian Gully, "Arabic Linguistic Issues and the Controversies of the Late Nineteenth and Early Twentieth Centuries," Journal of Semitic Studies 42 (1997), 109-115; al-Mațwī, vol. 1, 459-576; Muhammad 'Alī al-Zarkān, al-Jawānib al-lughawiyyah 'inda Aḥmad Fāris al-Shidyāq (Damascus: Dār alFikr, 1988).

69 See e.g. Jeffrey Sacks, Iterations of Loss. Mutilations and Aesthetic Form, Al-Shidyaq to Darwish (New York: Fordham University Press, 2015), 91-121; El-Ariss; Kamran Rastegar, Literary Modernity Between Middle East and Europe: Textual Transactions in Nineteenth-Century Arabic, English, and Persian Literatures (London: Routledge, 2007), 101-125; Peled; Zakharia, 509-521, Junge, Die Entblößung der Wörter, 90-289. 
produce an Oriental book of such enormous scale..$^{70}$ Publishing 760 pages in one volume, the book contains some $25^{\circ}$ pages of enumeration and is thereby able not only to claim the infinity of lists and language, but to produce and perform such an infinity by the sheer materiality of the pages.

\section{Classical Language as a Modern Lens}

In his speech on "The Arts of the Arabs" (Khuțbah fi àdāb al-'arab), delivered 1859 in Beirut, the influential public intellectual Buțrus al-Bustānī (d. 1883) discusses the state of the Arab sciences and also deals with the Arabic language that he describes as "a wide field of reform." ${ }^{\text {"11 }} \mathrm{He}$ states that in former times, the old Bedouin Arabs ('arab) were eager to describe every detail of the camel, so that the classical Arabic language now holds more names for the camel than the camel has hairs, while at the same time, Arabic lacks many terms for technical inventions and civilizational matters. As a result, it is overloaded with archaic words while it lacks modern expression. "But what is the use of these [old] expressions for a civilization that replaces the service of camel with that of [railway] wagons?"72 Instead of collecting the premodern and untimely lexis, one should rather seek to express the needs of modern civilization by coining a new language. Within the civilizational project of the Nahdia, this is an attempt at trimming and disciplining the language into civilizational service. ${ }^{73}$

In al-Sāq, al-Shidyāq also tries to express the civilizational needs but does so by using extensively the classical language. In regard to al-Bustān's phrase, one might say that al-Shidyāq tries to describe the era of the railroad with the words of the camel. One example is his enumerative description of Paris. Since Rifā‘ah Rāfi al-Ṭahțāwì’s (d. 1873) groundbreaking travelogue on Paris was published in $1834,{ }^{74}$ the nahḍawi description of Paris played a central role for accessing European modernity in Arabic travelogues. In his factual travelogue, Kashf al-mukhabbä' 'an funūn Ürubbā (Unveiling the Hidden in the Arts of Europe, 1867), al-Shidyāq approaches Paris with an enumeration of figures,

70 al-Shidyāq, vol. 4, 482. See A. Perrault, "À MM les auteurs ou éditeurs," in al-Shidyaq, al-Sāq 'alā l-sāq, back cover endorsement.

71 Buțrus al-Bustānī: "Khuṭbah fì ādāb al-'arab" in Fakhrī, 167.

72 al-Bustānī, "Khuțba," 167:

$$
\text { "فا هي الفائدة للحضر من هذه العبارات مع ا ستغنائهم بالعربات عن خدمة الابل" }
$$

73 For al-Bustānīs speech, see Sacks, 79-91; see also Jens Hanssen and Max Weiss, "Language, Mind, Freedom and Time. The Modern Arab Intellectual Tradition in Four Words," in Arabic Thought Beyond the Liberal Age. Towards an Intellectual History of the Nahda, ed. ibid. (Cambridge: Cambridge University Press, 2016), 14-18.

74 See Tarek El-Ariss, Trials of Arab Modernity. Literary Affects and the New Political (New York: Fordham, 2013), 19-52. 
counting for instance 21 boulevards and 183 shopping passages, thereby using the French loanwords bulafär and basāj. ${ }^{75}$ In his fictional travelogue al-Sāq, in contrast, the protagonist describes the public space of Paris using 25 words from the lexical field of 'commercial establishments'; the protagonist sees "eating houses, drinking houses, shops, warehouses,"76 and so on. This enumeration includes rare Persian loanwords like kurbaj, qurbaj, and qurbaq that show no cultural relation to the urban space of nineteenth-century Paris. ${ }^{77}$ By describing Paris with these 'foreign Persian words,' one after another and without any cultural translation referring to France, the enumeration is less an account of Paris, but an expression of how strange Paris is in the eyes of the Arab traveler. The astonishing aura of Paris is here effectively produced by old Persian loanwords rather than by new French ones: archaic words express modern sentiment.

But can the classical language articulate a particular nahḍawī reform project? In an enumerative essay on elitist male gender roles in Mount Lebanon, the narrator is criticizing gender segregation and demanding that fathers take better care of their children. While many nahḍawī intellectuals, like al-Bustānī, were eager to reform the family, mostly by installing a 'new mother,'78 al-Shidyāq's plea for a 'new father' is rather uncommon in mid-nineteenth century debates. In al-Sāq, the narrator argues that a father should spend time with his children. What is the benefit of having a child, he asks rhetorically, if you don't 'say to him: I would give my father as your ransom' (tuba'bi'uhu) or if you do not 'show affection for him' (tar'amuhu), and so on. ${ }^{79}$ Most of the words from this catalogue do not refer to the fatherly role, like ra'ima. According the common classical usage, it refers to a she-camel and means: she "displayed affection for her child, and she stayed close by it." ${ }^{\prime 0}$ By detaching words from their proper context and transferring them to a new context, $a s-S \bar{a} q$ indeed makes use of the words for camels to articulate a nahḍawi gender reform. This de- and recontextualization of words, that is for Mainberger so fundamental to the operation of

75 See Aḥmad Fāris al-Shidyāq, al-Wāsițah fì márifat aḥwāl Mãliṭah wa-Kashf al-mukhabbā 'an funūn Ūrūbbā, 1834-1857, ed. Qāsim Wahb (Beirut: al-Mu'assasah al-'Arabiyyah li-l-Dirāsāt wa-l-Nashr, 2004), 330. For Kashf, see El-Ariss, Trials of Arab Modernity, 53-87.

76 Al-Shidyāq, vol. 4, 249.

77 See Abū Manșūr al-Jawālīqī, Kitāb al-Mu'arrab min al-kalām al-ajamī 'alā ḥurūfal-mújam, ed. Aḥmad Muhammad Shākir (Cairo: Mațba'at Dār al-Kutub, 1969), 54-55, 328, 340.

78 See Fruma Zachs: "Feminism for Men: A Note on Butrus al-Bustani's Lecture on the Education of Women," in Butrus al-Bustani. Spirit of the Age, ed. Adel Beshara (Melbourne: IPhoenix Publishing, 2014), 113-128.

79 See al-Shidyāq, Leg over leg, vol. 3, 240-244.

$80 \quad$ al-Shidyāq, Leg over leg, vol. 3, 241:

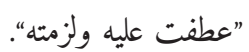


lists, performs an act of lexical 'deterritorialization.'81 For Gilles Deleuze and Félix Guattari this is the "the movement by which 'one' leaves the territory," i.e., a transgression out of a given regime of signs, thereby seeking to create new ways of signification. ${ }^{82}$ These enumerative games deterritorialize the 'words of the camel' and other archaic words for the expression of modern needs. This uncommon combination earns al-Sāq, as the German orientalist Emil Rödiger (d. 1874) called it in 1856 , "a strange and modern paint." 83

\section{Words as Archives for Cultural Identity}

Words do not only provide means for communication, but may also hold kernels of cultural identity. In Arab culture, the Arabic language has always been central to the imagined community and the pride in the lexical richness of al-'arabiyyah was omnipresent. ${ }^{84}$ This pride was problematized by al-Bustānī in his speech, when he claims that Arabic is a poor language, precisely because it holds so many words that are not useful for civilizational progress. ${ }^{85}$ Al-Shidyāq, on the contrary, argues throughout his works that the Arab civilization is mainly based on language, while other civilizations are based on technological inventions or material products. ${ }^{86}$ For him, the classical language is a major matrix of cultural identity and its wisdom and beauty may fruitfully contribute to nineteenth-century civilization.

In al-Saq, in particular, he argues that the verbal richness of lexical fields like those for the camel or the sword expresses their high cultural value for the old Arabs: the more words a thing has, the more value it contains. ${ }^{87}$ In this regard, mapping lexical fields becomes a way of mapping cultural identity and enumerative length becomes an indicator of importance. However, al-Sāq neither maps the lexical fields of the camel or the sword, but that of women. The protagonist is passionate about "words related to women" (hurüf nisǟìyyah) ${ }^{88}$

\footnotetext{
81 See Mainberger, 12-13.

82 See Gilles Deleuze and Félix Guattari, $A$ Thousand Plateaus, trans. Brian Massumi, 5 th ed. (London: Bloomsbury, 2016), 591, see also 129-172.

83 Emil Rödiger, "Wissenschaftlicher Jahresbericht über das zweite Halbjahr 1854 und das Jahr 1855," Zeitschrift der Deutschen morgenländischen Gesellschaft 10 (1856), 752.

84 See Yasir Suleiman, Arabic in the Fray. Language Ideology and Cultural Politics (Edinburgh: Edinburgh University Press, 2013), 1-50.

85 See also Georgine Ayoub, "Parier sur la langue," in Histoire de la littérature arabe moderne, Vol. 1: 180o-1945, ed. Boutros Hallaq and Heidi Toelle (Arles: Actes Sud, 2007), 289-301.

86 See Aḥmad Fāris al-Shidyāq, Mukhtarāt min āthār Aḥmad Fāris al-Shidyāq, ed. Yūsuf Qazmā Khūrī (Beirut: al-Mu’assasah al-Sharqiyyah li-l-Nashr wa-l-Ṭibā'ah, 2001), 391-392; Aḥmad Fāris, "al-Ḥamd li-llāh," in Ibn Manzūur, vol. 1, 2-3.

87 See al-Shidyāq, Leg over Leg, vol. 3, 148-150.

88 Ibid., 318; my translation.
} 
and seeks to collect all of them. In the nahḍawi discourse of female emancipation and the 'new woman,' al-Sāq seeks to unveil the virtues of women that it considers to be far higher than those of men. ${ }^{89}$ After enumerating 41 words for 'big-buttocked women,' for instance, the narrator concludes: "Does 'His Honor Our Lord the Most Excellent' judge or 'Our Venerated' emir have half as many names and sobriquets?"90 And in an enumeration of 219 words for "beautiful women,' the narrator goes to great lengths in order to perform the importance of a woman to a man, ${ }^{91}$ so he elsewhere exclaims: "What is the world if not women!"92

This mapping is, of course, highly selective. It does not, for instance, provide the many names for the old woman, but prefers young and attractive women. It also shows little interest in the sociohistorical living conditions of women in ancient Arabia. Rather, it detaches the word from its historical context and philological contexts and recontextualizes it in nineteenth-century society; it looks for a "potential modernity" (hadāthah mumkinah), ${ }^{93}$ after Raḍwā 'Āshūr, within these archaic words. In so doing, it thinks of the modern discourse of gender through the lens of deterritorialized archaic words-and this leads sometimes to indeed rather uncommon perspectives.

By compiling the many erotic and sexual words of Arabic, it stands up for eroticism and bodily pleasures that were often depreciated in the nahdiawi discourse and subordinated to intellectual pleasures. ${ }^{94}$ Yet by mapping its rich lexis, it claims that eroticism is an indispensable feature of Arab cultural identity. When the protagonist comes to Alexandria, he witnesses the charms of veiled woman flirting with men: "She bewitches them with [...] her expressive looks and glances, her come hither-winks and cow-eyes"95 and so on in an enumeration of 166 words. This enumeration not only maps the many arts of flirtation and affirms them to be part of Arab cultural identity, but also celebrates their words by arranging them to an artful rhymed and rhythmic prose:

89 See Zachs and Halevi, 16-41, 149-152.

$90 \quad$ al-Shidyāq, Leg over Leg, vol. 3, 156-157:

91 See ibid., vol. 2, 194-218.

"فهل للجناب مولانا القاضى المكرم ولاميرنا المعظم نصف هذه الاسماء والنعوت".

انما الدنيا النساء.Hadel.

93 Raḍwā 'Āshūr, al-Hadāthah al-mumkinah: al-Shidyāq wa-l-Sāq 'alā al-sāq. Al-Riwāyah al-ūlā fì l-adab al-'arabī al-hadīth (Cairo: Dār al-Shurūq, 2009), 131-133. While 'Āshūr describes it as a possible counter-modernity to the European colonial modernity, this article accentuates rather the potentiality of thinking of the modern through the classical language without essentially moving beyond it.

94 See Samir Khalaf, Protestant Missionaries in the Levant. Ungodly Puritans, $1820-60$ (London: Routledge, 2012), 65-67; Jirjis Khūlī, "al-Ladddah," in al-Muqtațaf 16.2 (1891), 85-88.

95 al-Shidyāq, Leg over Leg, vol. 2, 40-41. 
"bi-ramzihā wa-lamziha ${ }^{*}$ wa-hajlihā wa-ghamzihā." In al-Sāq, the enumerative length and arrangement do not only serve linguistic matters, but perform an ontic operation of imagining a community. The many compiled erotic and sexual words, however, never became common ground of the nahdiawi community; instead, al-Sāq was fervently criticized for listing all these words "that embarrass a young man, let alone a young woman," as the public intellectual Jurjī Zaydān (d. 1914) maintained. ${ }^{96}$

\section{Unveiling the Women's View}

While the so far discussed 'words of women' reproduced a male (heterosexual) perspective, the female protagonist al-Fāriyāqiyyah unveils a female (heterosexual) view on the world in order to represent women's needs. In the later nahḍah discourse, women like Maryānā Fatḥ Allāh Marrāsh were the first to take visible part in an open debate about the role of women. In her article "The Beauty Spot of al-Jinān" (Shämat al-Jinān, 1870), published in al-Bustānī's Beirut-based journal al-Jinān (The Gardens), she very eloquently demands the access of women to education and public discourse while at the same time brilliantly performing her linguistic skills. ${ }^{97}$ For al-Shidyāq in 1855 , however, the existence of an eloquent female protagonist using the same sophisticated words of her husband seemed unlikely, as he confesses in the foreword. When al-Fāriyāqiyyah, nevertheless, shows an unrivalled linguistic mastery, she epitomizes what a woman can become under the right social circumstances; ${ }^{98}$ she is a utopian 'new woman.' As such, she ardently criticizes the male perspective and male dominated language: since Arabic is compiled by men, dictionaries contain only words expressing male needs. If women would have compiled them, they would have coined and compiled words like "men only think of their wives, and how men should avert their glances from all but these,"99 and so on. This inventory of gendered blind spots is a mapping of lexical gaps that unveil that dictionaries are-in feminist terms-phallogocentric products where the act of signification is dominated by the male and language is put in the service of the patriarchate. ${ }^{100}$ Indeed, while classical Arabic literature has

96 Jurjī Zaydān, "al-Shaykh Aḥmad Fāris al-Shidyāq," al-Hilāl 15 (April 1894), 453-456:

$$
\text { "يخجل من قراءته الشاب فضلاً عن العذراء". }
$$

97 Maryānā Marrāsh, "Shāmat al-Jinān," al-Jinān 1 (1870), 467-468; Zachs and Halevi, 23-24.

98 al-Shidyāq, Leg over Leg, vol. 1, 14.

99 Ibid., vol. 4, 134-135:

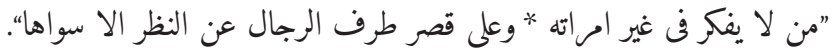

100 Emma L. E. Rees, "Phallogocentrism," in Encyclopedia of Feminist Literary Theory, ed. Elizabeth Kowaleski Wallace, 3rd ed. (London: Routledge, 2009), 434. 
some quite famous female poets, classical Arabic lexicography does not have, to my best knowledge, a well-known female lexicographer. ${ }^{101}$ In this phallogocentric language, can female desire be expressed at all?

Yes, it can. In a matrimonial dialogue with her husband, she claims that women feel the same or even more pleasure when looking at a male body than men looking at a female body. Her husband is astonished, since there are so many attributes for the female breast — and he enumerates some 60 - and so little for the male. Al-Fāriyāqiyyah, however, answers him with a catalogue of some $5^{0}$ words for 'hard and strong.' Is male pleasure, after all, still stronger? No, it is not, since the narrator supplements at the end of the chapter a list of some 100 words for 'hard and strong.'102 The final score of this matrimonial dispute (munāzarah) on male versus female pleasure counts 80 to 140; enumerative length makes the pleasure's strength. Throughout the book, the utopian new woman al-Fāriyāqiyyah is engaged in enumeration to unveil gendered blind spots, deterritorializes words, and revaluates language for female needs and is thereby the "first feminist character in modern Arabic literature,"103 as Radiwā 'Āshūr has called her.

In al-Sāq, enumerative games are "trials of Arab modernity," to use a term of Tarek El-Ariss, trying out what an Arab modernity could look like, such as the 'new woman' and the 'new man.'104 At the same time, they put contemporary concepts of modernity on a trial, questioning the puritanized modernity or the modern uselessness of synonyms. By using poetic devices like decontextualization, rhymed prose, and length, the here discussed lists, compilations, and inventories engage in politics: They turn archaic words into a lens of modernity, unearth cultural identities, and create new meanings. As a result, these lists challenge conceptions of the nahdah as radical epistemic rupture by foregrounding how a rereading of classical Arabic may help to shape a nahḍawī Arab modernity.

During the nineteenth-century, al-Shidyāq's al-Saq was often described as a very extraordinary work of Arabic literature. However, there were many other 'enumerative' trials of Arab modernity. In 1856, Nāṣîf al-Yāzijī published in Beirut his maqāmah compilation Majma' al-bahrayn (The Confluence of Two Seas), where he indulges in word compilations of onomatopoetic words

\footnotetext{
101 No female lexicographer or philologist appears, for instance, in the broad historical overview by Baalbaki, The Arabic Lexicographical Tradition.

102 See al-Shidyāq, Leg over leg, vol. 3, 166-172.

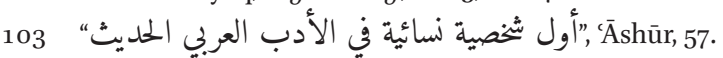

104 El-Äriss, Trials of Arab M̈odernity, 1-13.
} 
or words for horses, for instance. ${ }^{105}$ Unlike al-Shidyāq's $a s-S a \bar{q}$, however, he does not deterritorialize the archaic vocabulary spatially and geographically, but places it in a mythical past of the Islamic world; its nahḍawi newness operates here much more clandestinely. And while al-Sāq's lexicographical catalogues of synonyms have been criticized for being lexically obscure and detached from practical usage, ${ }^{106}$ it is Ibrāhīm al-Yāzijī who provides in his Nuj'at al-rā’id wa-shir'at al-wārid fì al-mutarādif wa-l-mutawārid (Asylum for He Who Searches, Source for He Who Arrives. On Synonyms and Words with Similar Meanings, 1904), published in Beirut, a practical tool for modern writing. Nevertheless, $a s-S a \bar{q}$ 's enumerative games remain a major contribution to the nahdah discourse, precisely because of its provocative and experimental 'thinking through language.' Together with his lexical thesaurus Sirr al-layāl fi l-qalb wa-l-ibdāl (The Secret of the Nights. On Metathesis and Substitution, 1868) published in Istanbul, that seeks to develop a new theory of etymology, al-Shidyāq shows how a compilation of words may change the understanding of the world.

\section{To Be Explored: Lists and Enumerative Games in Arabic Prose}

Enumeration in prose is a textual mode of close cohesion between fragmented items in a particular setting that establishes certain affinities between these items, thereby often 'doing things.' The approach to compilations, as suggested here, is to analyze items, length, arrangement, and frame as basic features of the poetics of the enumerative. In addition, in order to understand the politics of enumerative games, it is important to consider how compilations are used and read in a given discourse. In this regard, classical and modern Arabic prose literature offers a rich storehouse of various enumerative poetics and politics, most of which still remain to be explored.

\footnotetext{
105 See Matti Moosa, The Origins of Modern Arabic Fiction, 2nd ed. (London: Rienner, 1997), 95-97.

106 Yūsuf Shulhut, "Shawāib al-luġah al-'arabiyyah," al-Muqtațaf 17:5 (Feb. 1893), 305-306.
} 